medRxiv preprint doi: https://doi.org/10.1101/2021.04.18.21255682; this version posted April 27, 2021. The copyright holder for this preprint (which was not certified by peer review) is the author/funder, who has granted medRxiv a license to display the preprint in perpetuity. It is made available under a CC-BY-NC-ND 4.0 International license .

\title{
Effective vaccine allocation strategies, balancing economy with infection control against COVID-19 in Japan
}

Satoshi Sunohara $^{1, \uparrow, ~ T o s h i a k i ~ A s a k u r a ~}{ }^{1,}$ ๆ, Takashi Kimura ${ }^{2, *}$, Shun Ozawa ${ }^{1}$, Satoshi Oshima1, Daigo Yamauchi $^{1}$ and Akiko Tamakoshi ${ }^{2}$

${ }^{1}$ School of medicine, Hokkaido University, Kita 15, Nishi 7, Kita-ku, Sapporo,060-8638, Japan

${ }^{2}$ Public health, Faculty of Medicine, Hokkaido University, Kita 15, Nishi 7, Kita-ku, Sapporo,0608638, Japan

* Corresponding author

E-mail: kimura@med.hokudai.ac.jp (TK)

These authors contributed equally to this work. 
medRxiv preprint doi: https://doi.org/10.1101/2021.04.18.21255682; this version posted April 27, 2021. The copyright holder for this preprint (which was not certified by peer review) is the author/funder, who has granted medRxiv a license to display the preprint in perpetuity. It is made available under a CC-BY-NC-ND 4.0 International license.

\section{Abstract}

Due to COVID-19, many countries including Japan have implemented a suspension of economic activities for infection control. It has contributed to reduce the transmission of COVID-19 but caused severe economic losses. Today, several promising vaccines have been developed and are already being distributed in some countries. Therefore, we evaluated various vaccine and intensive countermeasure strategies with constraint of economic loss using SEIR model to obtain knowledge of how to balance economy with infection control in Japan. Our main result is that the vaccination strategy that prioritizes younger generation outperformed the other strategies in terms of deaths. On the other hand, when we focused on strategies that prioritize older generation, as Japan has decided to do, the optimal vaccination strategy was determined by the basic reproduction number and acceptable economic loss. The strategy vaccinating the young next to the old age group was the best when acceptable economic loss was high, or the basic reproduction number was low. Alternatively, the strategy vaccinating the middle next to the old age group was superior to the others with a moderate acceptable economic loss and the high basic reproduction number setting. 
medRxiv preprint doi: https://doi.org/10.1101/2021.04.18.21255682; this version posted April 27, 2021. The copyright holder for this preprint (which was not certified by peer review) is the author/funder, who has granted medRxiv a license to display the preprint in perpetuity.

\section{Introduction}

At the end of 2019, an outbreak of coronavirus disease 2019 (COVID-19) caused by the SARS-CoV-2 virus began in Wuhan City (Hubei Province, China) [1,2]. COVID-19 has affected tens of millions of people worldwide since it was declared to be a pandemic by the World Health Organization on March 11th, 2020. As of April 1st, 2021, the death toll was over 2.8 million worldwide and over 9,000 in Japan [3].

Due to this pandemic, many countries have implemented a suspension of economic activities (usually referred to as a lockdown) with restrictions on movement [4,5]. It has been observed that the implementation of the lockdown reduces contact rate and thus transmission of SARS-CoV-2 [6-9]. On the other hand, lockdowns stopped economic activity and caused severe economic losses [1012]. In Japan, no enforceable policy of movement restrictions was implemented, but the government declared a state of emergency, not a strict lockdown, to control the spread of SARS-CoV-2. This declaration allowed prefectural governors to take measures such as restricting the operation of public facilities, including schools, and reducing the hours of operation of restaurants $[13,14]$. This measure resulted in economic losses like lockdown policies in other countries. In the situation of pandemic of COVID-19, the world's GDP and Japan's GDP were estimated to have shrunk by $5.2 \%$ [15] and by $4.8 \%$ [16] in 2020, respectively.

Today, unlike the situation at the time of the emergence of SARS-CoV-2, several promising vaccines have been developed and are already being distributed in some countries [17]. In Japan, vaccination in healthcare workers has begun in March 2021, and vaccination in the general elderly population has been implemented from April 12th, 2021. However, until herd immunity is established by vaccinating a certain percentage of the population, it is necessary to continue controlling contacts as a preventive measure against infection. This will require knowledge of how to balance economy with infection control under progression of vaccination. 
medRxiv preprint doi: https://doi.org/10.1101/2021.04.18.21255682; this version posted April 27, 2021. The copyright holder for this preprint (which was not certified by peer review) is the author/funder, who has granted medRxiv a license to display the preprint in perpetuity. It is made available under a CC-BY-NC-ND 4.0 International license .

Therefore, we evaluated various vaccine and intensive countermeasure strategies with constraint of predefined amount of economical loss using SEIR model. 
medRxiv preprint doi: https://doi.org/10.1101/2021.04.18.21255682; this version posted April 27, 2021. The copyright holder for this preprint (which was not certified by peer review) is the author/funder, who has granted medRxiv a license to display the preprint in perpetuity. It is made available under a CC-BY-NC-ND 4.0 International license.

\section{Materials and methods}

\section{Simulation scenarios}

We assumed that vaccine was started to be distributed at the start of the simulation and that all individuals received vaccination within one year at a constant rate. We used a lockdown as one of intensive countermeasures. Acceptable economic loss was predefined and intensity, length and start timing of the lockdown were optimized to minimize the cumulative number of deaths at the end of the simulation, comparing with different vaccination strategies. It is noted that the lockdown used in this study is defined as countermeasures not only reducing transmissibility but also causing economical damage. Our usage of the lockdown includes containment and closure indicators of OxCGRT indicators [13], for example workplace closing, cancel public events, restrictions on gathering size and stay-at-home requirements. On the other hand, neither countermeasures without economical damage (ex. mask wearing, improving hand hygiene and public information campaign) nor economical supports are included in our usage of the lockdown.

We divided population into young (15-49 years old), middle (50-64 years old) and old (more than 64-year-old) populations and ignored child age group (0-14 years old) since age was critical factor for contact rates and mortality, and also for simplicity of simulation settings [18]. 10 vaccine allocation strategies were compared in the present study. One scenario was equal allocation for all age groups. 6 scenarios were precise prioritization for 3 generations. For example, old generations were targeted at first. If all old individuals received vaccination, the next target was middle age group. After that, young generations received vaccination. The other 3 scenarios were partial prioritization strategies. One age group was targeted at first and the rest of vaccines were allocated equally to the other two age groups.

Regarding lockdown strategies, it was assumed that the lockdown was performed only once during each simulation. To balance economy with infection control, we varied three parameters 
medRxiv preprint doi: https://doi.org/10.1101/2021.04.18.21255682; this version posted April 27, 2021. The copyright holder for this preprint (which was not certified by peer review) is the author/funder, who has granted medRxiv a license to display the preprint in perpetuity. It is made available under a CC-BY-NC-ND 4.0 International license .

related with the lockdown: start timing, $t_{\mathrm{s}}$, intensity for age group $j, L_{\mathrm{j}}$, and length, $T_{\mathrm{L}}$, of the lockdown. In our main analyses, the lockdown was equally imposed to all generations so that $L_{\mathrm{j}}=L$ for any age group.

Economic loss refers to a proportion of loss of production value of each individual due to the lockdown and defined as

$$
E=\frac{\sum_{j} w_{j} N_{j} \theta L_{j} T_{L}}{\sum_{j} w_{j} N_{j} 365}
$$

where $w_{\mathrm{j}}$ and $N_{\mathrm{j}}$ was an average production value and the number of populations for age group $j$, respectively. $\theta$ was defined as lockdown efficacy and we assumed $25 \%$ of population would not be affected by the lockdown. We did not consider loss of production caused by any other countermeasures.

In addition to analysis with 1.3 of $R_{0}$ setting, we performed sensitivity analysis varying the basic reproduction number. Also, we performed the same analysis with age group specific lockdown intensity, $L_{\mathrm{j}}$, for the case of 1.3 of $R_{0}$.

Optimization was done with differential evolution implemented in a python package, scipy version 1.5.3 [19,20].

\section{SEIR model scheme}

Schematics of our SEIR model is shown in Fig 1. Our model consisted of contact matrix, infection fatality ratio (IFR) and vaccinated and unvaccinated compartments for simulating infection dynamics of age-stratified populations with vaccination. We refers $S_{\mathrm{j}, \mathrm{u}}$ and $S_{\mathrm{j}, \mathrm{v}}$ as unvaccinated and vaccinated susceptible populations of age group $j$. Exposed, infected and recovered populations are similarly defined. Vaccines were distributed at a rate of $p_{\mathrm{j}} / T_{\mathrm{vac}} N_{\mathrm{j}, \mathrm{u}}$ for each compartment where $T_{\mathrm{vac}}$ is the whole interval of vaccination, $N_{\mathrm{j}, \mathrm{u}}$ is total number of unvaccinated population and $p_{\mathrm{j}}$ is timevarying parameters taking between 0 to 1 determined by vaccine allocation strategies. For old-other strategies, $p_{\mathrm{o}}$ takes 1 for old age group at the end of their vaccination and the others are 0 . After that, 
medRxiv preprint doi: https://doi.org/10.1101/2021.04.18.21255682; this version posted April 27, 2021. The copyright holder for this preprint (which was not certified by peer review) is the author/funder, who has granted medRxiv a license to display the preprint in perpetuity. It is made available under a CC-BY-NC-ND 4.0 International license.

$p_{\mathrm{y}}$ and $p_{\mathrm{m}}$ take percentage of population among two to distribute vaccine according to population size until the whole population is vaccinated. Vaccine effect is assumed to be leaky one, meaning that vaccinated populations were less likely, not completely, to be infected compared to unvaccinated individuals. Infected and recovered individuals also received vaccination in our model. There are two reasons for this. One reason is that insufficient immunity has been controversial now [21], and that vaccination would contribute to reduce reinfection. The second reason is that asymptomatic individuals are difficult to be separated from susceptible ones without tests.

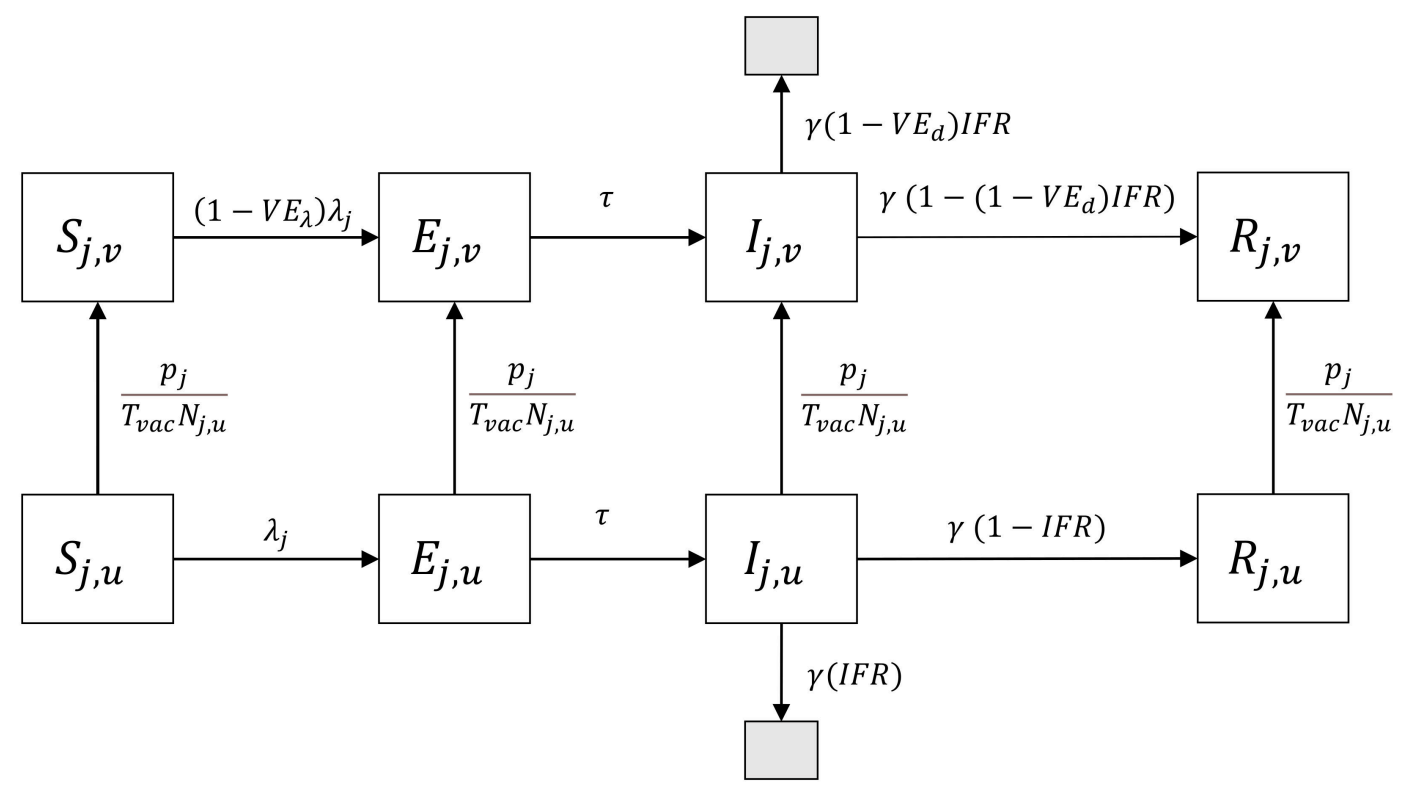

Fig 1. Schematic of SEIR model composed of vaccinated and non-vaccinated compartments. Subscript $j$ represents young, middle or old age group. Black shaded box represents death status.

\section{Force of infection and basic reproduction number}

Force of infection for age group $j, \lambda_{\mathrm{j}}$, is an inflow rate from susceptible population to exposed population. Taking lockdown effect into account, force of infection for age group $j$ is derived as

$$
\lambda_{j}=u\left(1-\theta L_{j}(t)\right) \sum_{k} \rho_{j k}\left(1-\theta L_{k}(t)\right)\left(I_{k}(t)+I_{k, v}(t)\right)
$$


medRxiv preprint doi: https://doi.org/10.1101/2021.04.18.21255682; this version posted April 27, 2021. The copyright holder for this preprint (which was not certified by peer review) is the author/funder, who has granted medRxiv a license to display the preprint in perpetuity. It is made available under a CC-BY-NC-ND 4.0 International license.

where $u$ is a successful transmission rate given one contact, and $\rho_{\mathrm{jk}}$ is a contact rate for age group $j$ with age group $k$.

The basic reproduction number was calculated from absolute of the dominant eigen value of the matrix $M$, which was the product of a matrix $\mathrm{C}$ and a diagonal matrix of which element was $u / \gamma$ where $1 / \gamma$ was infectiousness period. The matrix $\mathrm{C}$ represents contact matrix weighted by population size which elements were written as $\rho_{\mathrm{jk}} N_{\mathrm{k}}$. This kind of the matrix $M$ was derived from the methodology described in [22].

\section{Parameter specification}

Parameters used in this study are summarized in Table 1. Most parameters came from resources in Japan in order to perform simulation under the Japanese setting. We had to modify several original data to be compatible with our model, which were contact rates, IFR and production values. 
medRxiv preprint doi: https://doi.org/10.1101/2021.04.18.21255682; this version posted April 27, 2021. The copyright holder for this preprint (which was not certified by peer review) is the author/funder, who has granted medRxiv a license to display the preprint in perpetuity. It is made available under a CC-BY-NC-ND 4.0 International license .

Table 1. Summary of parameters used in the simulations.

\begin{tabular}{|c|c|c|c|}
\hline Symbols & Descriptions & Values & References \\
\hline$\tau$ & 1/ Latent period (/day). & $1 / 3$ & {$[23]$} \\
\hline$\gamma$ & 1/ Infectiousness period (/day). & $1 / 5$ & {$[24]$} \\
\hline$u$ & $\begin{array}{l}\text { Transmission rate given one } \\
\text { contact. }\end{array}$ & 0.05882 when $R_{0}=1.5$ & Calculation \\
\hline$\rho_{j k}$ & $\begin{array}{l}\text { Contact matrix } \\
\text { for age group } j \text { with age group } k^{\dagger} \text {. }\end{array}$ & $\begin{array}{l}{[[10.482,1.567,} \\
0.332], \\
{[7.250,3.506,0.879],} \\
[3.105,1.789,2.926]]\end{array}$ & {$[25]$} \\
\hline$I F R_{\mathrm{j}}$ & $\begin{array}{l}\text { Infection fatality ratio } \\
\text { for age group } i(\%){ }^{\dagger}\end{array}$ & {$[0.030,0.295,4.893]$} & {$[26]$} \\
\hline$N_{\mathrm{j}}$ & $\begin{array}{l}\text { Population for age group } j\left(\times 10^{3}\right) \\
\dagger\end{array}$ & {$[50557,23987,36155]$} & {$[27]$} \\
\hline $\begin{array}{l}{[E(0), I(0),} \\
\quad R(0)]\end{array}$ & $\begin{array}{l}\text { Initial number for } \mathrm{E}, \mathrm{I} \text { and } \mathrm{R} \\
\text { compartments }^{*} \text {. }\end{array}$ & {$[9540,18685,358145]$} & {$[28]$} \\
\hline$\theta$ & Lockdown efficiency. & 0.75 & Assumption \\
\hline$w_{\mathrm{j}}$ & $\begin{array}{l}\text { Production value for age group } j \\
\left(\times 10^{3} \text { yen }\right)^{\dagger}\end{array}$ & {$[3742,4474,812]$} & {$[29,30]$} \\
\hline$V E_{\lambda}$ & Vaccine efficacy for transmission. & 0.95 & {$[31]$} \\
\hline$V E_{d}$ & Vaccine efficacy for death. & 0.84 & {$[32]$} \\
\hline
\end{tabular}

${ }^{\dagger}$ The order of values listed is young, middle and old age group.

* These values were assigned to each age group proportional to population size.

For contact rates, we denote $x_{5 \mathrm{i}, 5 \mathrm{j}}$ as original contact rates of a person among $5 i$ to $5(i+1)-1$ age interval with a person among $5 j$ to $5(j+1)-1$ age interval and $N_{5 \mathrm{i}}$ represents population size for $5 i$ to $5(i+1)-1$ years old. We combined rows for each age interval, and took weighted summarization for columns by population size. For example, contact rate of young group with middle group, $\rho_{\mathrm{ym}}$, was calculated as

$$
\rho_{y m}=\frac{\sum_{i=3}^{9} N_{5 i} \sum_{j=10}^{12} x_{5 i, 5 j}}{\sum_{i=3}^{9} N_{5 i}}
$$

where contact rates for young with middle age group were summed over from 50-54 to 60-64 age interval and were weighted by each age interval from 15-19 to 45-49 age interval. Similar calculation was done for other age group pairs, noting that we ignored population from 0 to 14 years old. The 
medRxiv preprint doi: https://doi.org/10.1101/2021.04.18.21255682; this version posted April 27, 2021. The copyright holder for this preprint (which was not certified by peer review) is the author/funder, who has granted medRxiv a license to display the preprint in perpetuity. It is made available under a CC-BY-NC-ND 4.0 International license.

contact rates of reference paper did not have the ones of age more than 79 years old, so that we copied rows and columns of 75-79 years old diagonally. We multiplied 0.9 for these rows and columns since we considered older populations had lower contact rate than that of 75-79 years.

The reference of IFR [26] showed that the relationship between IFR and age was exponential. Since we were able to calculate infection fatality ratio at any age using this relationship, IFR of each age group was calculated as weighted means of IFR for each 5-age interval. For example, the equation for young age group was derived as

$$
I F R_{y}=\frac{\sum_{i=3}^{9} N_{5 i} I F R_{5 i+2}}{\sum_{i=3}^{9} N_{5 i}}
$$

where $I F R_{5 i+2}$ represents the infection fatality rate at age $5 i+2$, which is a median of each age interval. For old age group, more than 80 years old were grouped as one and we chose IFR at 85 years old for this group.

Production value was intended to reflect production values by workers. We obtained values of salary for each 5-age intervals, and weighted summaries by population size were used for production value for each age group, $w_{\mathrm{j}}$.

We set the initial number of each SEIR component as the status on 1st February 2021 in Japan. We set initial value for $E_{\mathrm{j}}$ as sum of newly reported cases during 29th to 31 st January 2021 multiplied by a percentage of population size for age group $j$ and for $I_{\mathrm{j}}$ and $\mathrm{Rj}$ as sum of ones during 23rd to 28th January 2021 and the cumulative number of cases till 22nd January 2021, respectively, multiplied by the same percentage. Actual values can be seen in Table 1. 
medRxiv preprint doi: https://doi.org/10.1101/2021.04.18.21255682; this version posted April 27, 2021. The copyright holder for this preprint (which was not certified by peer review) is the author/funder, who has granted medRxiv a license to display the preprint in perpetuity. It is made available under a CC-BY-NC-ND 4.0 International license .

\section{Results}

Fig 2 illustrates the relationship between economic loss and lockdown intensity and length values. $\mathrm{x}$ and $\mathrm{y}$ axis represent intensity and length of the lockdown and $\mathrm{z}$ axis represents the cumulative number of deaths at the end of the simulation. Optimization of parameters $\left(T_{\mathrm{L}}, L\right.$ and $\left.t_{\mathrm{s}}\right)$ for the lockdown imposing equally to each age group was done along each line drawn by constraint of predefined economic loss value, $E$. The start timing of the lockdown, $t_{\mathrm{s}}$, was usually 0 for almost all simulations. Then, we omitted the value of $t_{\mathrm{s}}$ from the following figures and tables.

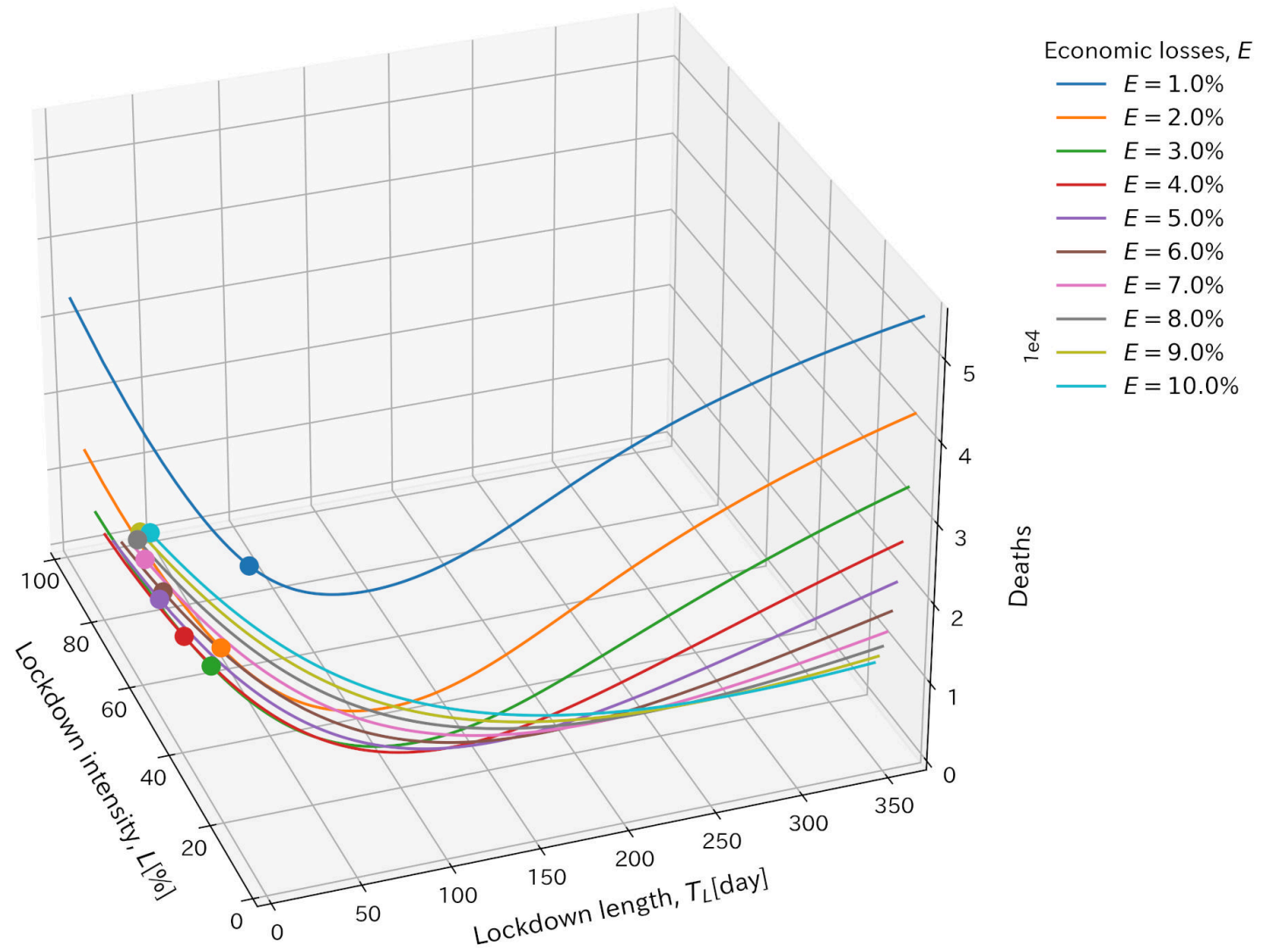

Fig 2. Illustration of relationship between economic loss and lockdown intensity and length

values. $x$ and $y$ axis represent lockdown intensity and length values. $z$ axis represents the cumulative number of deaths at the end of the simulations. Each line was drawn with the same volume of 
medRxiv preprint doi: https://doi.org/10.1101/2021.04.18.21255682; this version posted April 27, 2021. The copyright holder for this preprint (which was not certified by peer review) is the author/funder, who has granted medRxiv a license to display the preprint in perpetuity. It is made available under a CC-BY-NC-ND 4.0 International license.

economic loss, $E$. Points show the minimum cumulative number of deaths for each line. Values at these points were used for the optimized parameters and shown in the following figures.

Fig 3 summarizes the cumulative number of deaths and infected population at the end of the simulations under 10 vaccine allocation strategies for each acceptable economic loss, together with the lockdown intensity and length giving optimal results (see S1 Table for detail). The lockdown was equally imposed to all generations and the basic reproduction number, $R_{0}$, was set to be 1.3. Overall, three young first strategies were the most effective in reducing the number of deaths and infections for most of the cases. The fourth effective strategy would be one that distributed vaccine equally to all age groups, especially in lower acceptable economic loss. The optimized values of the start timing of the lockdown, $t_{\mathrm{s}}$, were the start timing of the simulation, that is, 0 for the most of simulations. The strong lockdown with short interval was preferable for young first strategies since young population had high contact rates. Restricting and vaccinating this population simultaneously leaded to lower reproduction number. 
medRxiv preprint doi: https://doi.org/10.1101/2021.04.18.21255682; this version posted April 27, 2021. The copyright holder for this preprint (which was not certified by peer review) is the author/funder, who has granted medRxiv a license to display the preprint in perpetuity. It is made available under a CC-BY-NC-ND 4.0 International license .
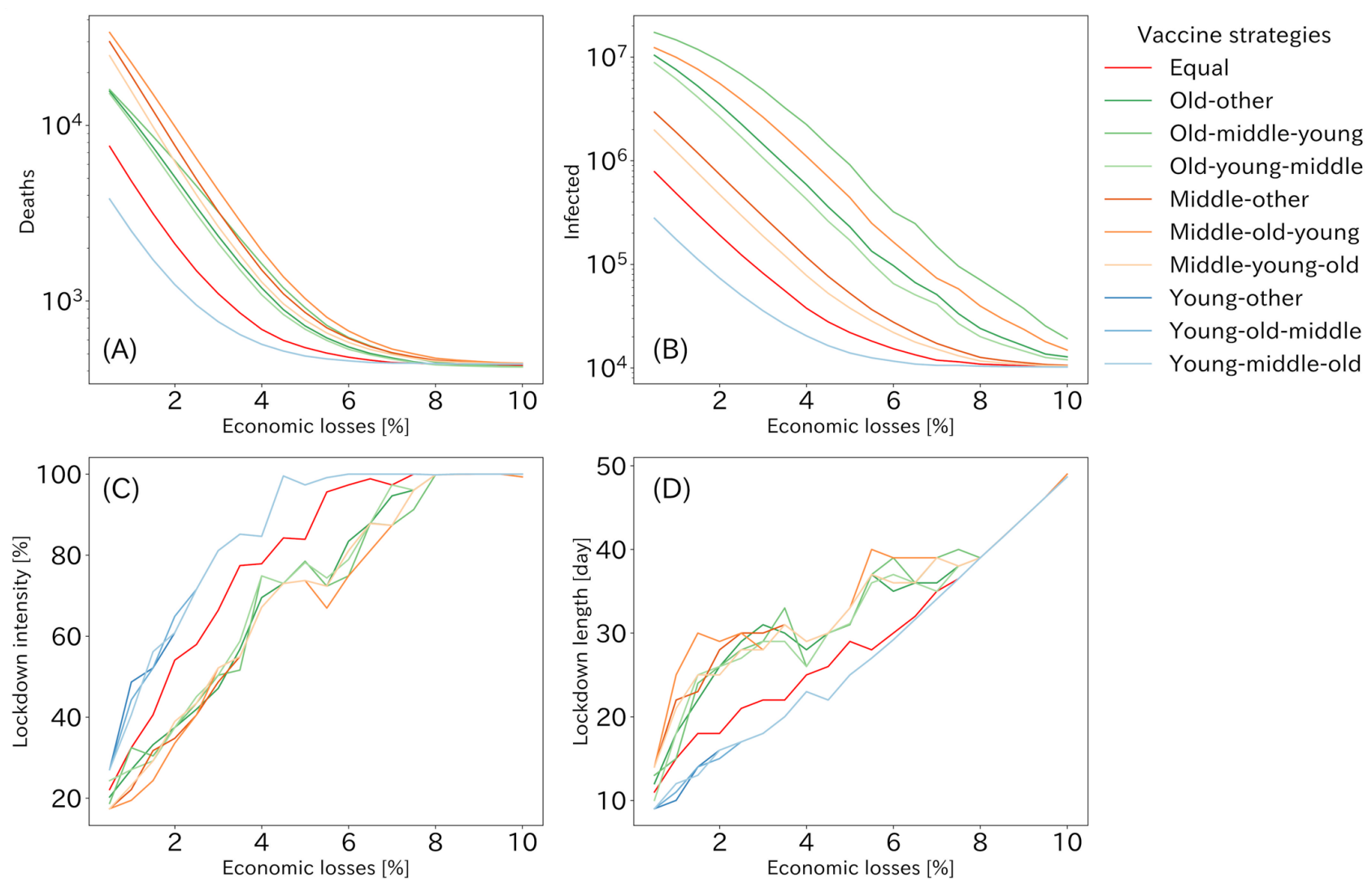

Fig 3. The optimized results and parameters for $R_{0}=1.3$ when the lockdown was imposed

equally to each generation. The optimized results of the cumulative number of deaths (A) and infected (B) populations for each economic loss. (C) and (D) represents the lockdown intensity and length, which value pattern produced the results of (A) and (B) for each economic loss. Although there are only eight lines visible in (A) and (B), three lines of young first vaccination strategies have overlain each other. The order of age groups on the label shows vaccine allocation strategies.

The cumulative numbers of the deaths for all strategies under 4 patterns of the basic reproduction number are shown in Fig 4. The best strategies were young first ones in terms of the cumulative number of deaths or infected population regardless of $R_{0}$ except the strong lockdown situation. In addition, the strategy distributing vaccine equally to all age groups was the fourth effective strategy in most sizes of economic losses under 1.5 of $R_{0}$. However, when $R_{0}$ was more than around 1.5, in situations where the lockdown was mild and caused little economic loss, three old first strategies were more effective than those of vaccinating all generations equally in terms of 
medRxiv preprint doi: https://doi.org/10.1101/2021.04.18.21255682; this version posted April 27, 2021. The copyright holder for this preprint (which was not certified by peer review) is the author/funder, who has granted medRxiv a license to display the preprint in perpetuity. It is made available under a CC-BY-NC-ND 4.0 International license.

deaths. When comparing strategies prioritizing vaccination to the old or middle age group, the old first strategies were more effective when the lockdown caused little economic loss, while the middle first strategies were more effective when there was much economic loss due to the lockdown. The differences in the effectiveness of the middle and old first strategies were more apparent for larger values of $R_{0}$.
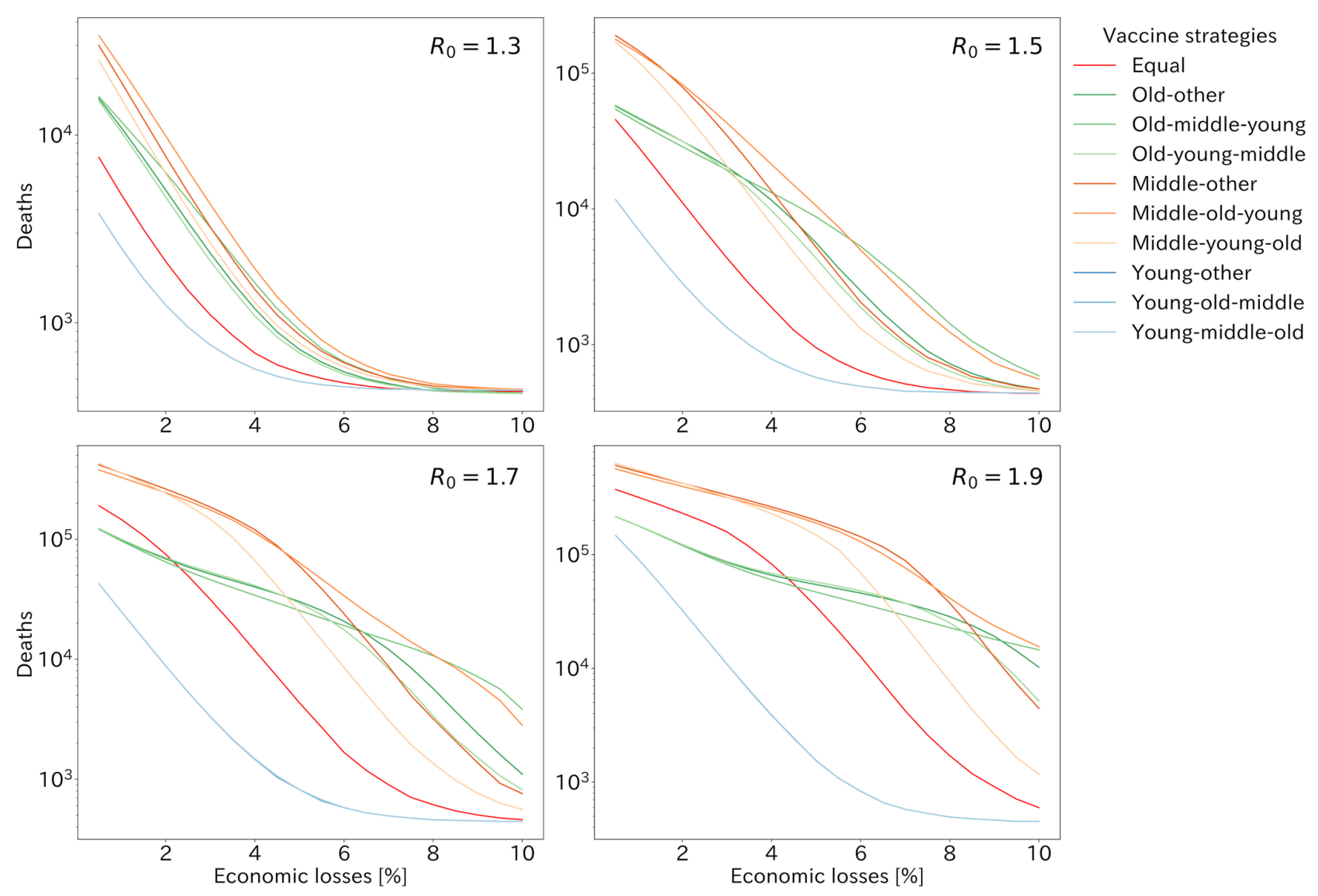

Fig 4. The cumulative number of deaths with $R_{0}$ taking $1.3,1.5,1.7$ and 1.9 when the lockdown was imposed equally to each generation. Each line shows vaccine allocation strategies. Three lines of young first vaccination strategies have overlain each other as Fig 3.

As Japan has already decided to vaccinate to the old age groups first, we compared three old first strategies in order to clarify which order of vaccination was better after the old age group was vaccinated. Fig 5 summarizes the best old first strategy among three strategies, old-middle-young, 
medRxiv preprint doi: https://doi.org/10.1101/2021.04.18.21255682; this version posted April 27, 2021. The copyright holder for this preprint (which was not certified by peer review) is the author/funder, who has granted medRxiv a license to display the preprint in perpetuity. It is made available under a CC-BY-NC-ND 4.0 International license .

old-young-middle and old-other strategies, varying $R_{0}$ (see S2 Table for detail). When $R_{0}$ was below 1.4 , the old-young-middle strategy was most effective in reducing deaths under almost all the economic loss patterns, whereas under larger $R_{0}$, the old-middle-young strategy started to excel greater than the other strategies for low acceptable economic loss.

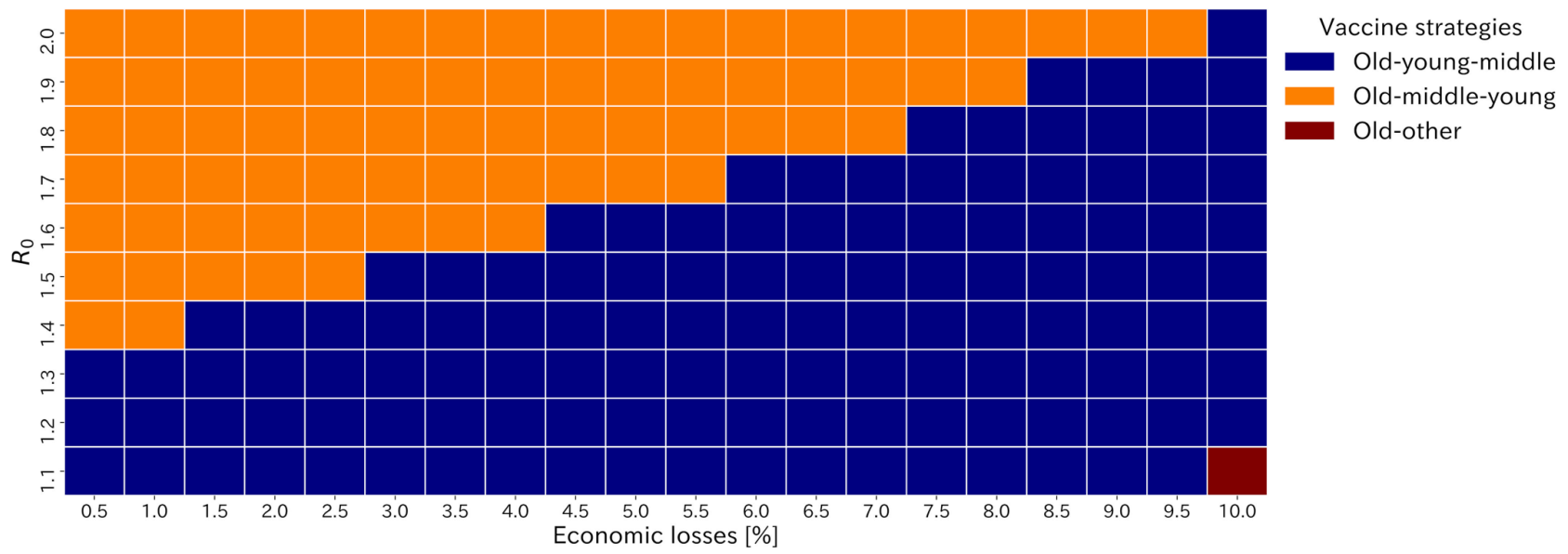

Fig 5. Heatmap of the best strategy in terms of the cumulative number of deaths among the old

first strategies varying $\boldsymbol{R}_{\mathbf{0}}$ and acceptable economic losses. It is noted that among all vaccine allocation strategies, young first strategy or the strategy distributing equally to each age group was generally better than the old first strategies though results are not shown in this figure.

We also performed simulations under settings of the lockdown being imposed with different intensities to each age group for 1.3 of $R_{0}$ (S3-S4 Figs). Over all trends of the cumulative number of deaths and infected population were similar as when the lockdown was equally imposed. To achieve optimal strategies, the strong lockdown to young and old age group was preferable to middle age group. 
medRxiv preprint doi: https://doi.org/10.1101/2021.04.18.21255682; this version posted April 27, 2021. The copyright holder for this preprint (which was not certified by peer review) is the author/funder, who has granted medRxiv a license to display the preprint in perpetuity. It is made available under a CC-BY-NC-ND 4.0 International license.

\section{Discussion}

We explored the better vaccine allocation and intensive countermeasure strategies to balance economic sustainability with infection control against COVID-19 in Japan. The young first strategies were better than any other strategies in lower acceptable economic loss and lockdown strategies. If we focused on the old first strategies, as Japan has decided to vaccinate the old populations first, the old-young-middle strategy was the best when the strong lockdown was imposed or the basic reproduction number, $R_{0}$, was low (Fig 5). On the other hand, the old-middle-young strategy was superior to the others with the mild lockdown and high $R_{0}$. These results came from the fact that young age group had the highest contact rates for all age groups [25] and was more likely to transmit infection so that vaccinating young populations at an early stage would prevent them from transmitting infection and enable population to reach herd immunity at the early stage, resulting in the containment of the epidemic and reduction of deaths.

Although the best strategies were three young first strategies for the most of simulations, the strategy distributing vaccine equally to all age groups was the best except the young first strategies for lower $R_{0}$ settings (Fig 4 ). However, in higher $R_{0}$ settings, the old first strategy was better than equally distributed strategy if acceptable economic loss was low. This can be explained as follows. In case of high $R_{0}$ and low acceptable economic loss, it is difficult to prevent the large epidemic of COVID-19, and the number of deaths can only be reduced by prioritizing vaccination to old populations, who have a higher mortality rate. While, in case of low $R_{0}$ or high acceptable economic loss, it is possible to control COVID-19 through the lockdown and vaccination.

Our results implied that the best strategy minimizing deaths was changed according to the value of $R_{0}$ and how countermeasures causing economical damage was imposed. $R_{0}$ of COVID-19 was estimated as more than 2 at early stage of the epidemic $[33,34]$. However, effective case tracing $[24,35]$ and much public awareness reduced transmissibility and some study handling with negative values of serial interval reported lower value of $R_{0}$ [36]. Also, our usage of a lockdown does not 
medRxiv preprint doi: https://doi.org/10.1101/2021.04.18.21255682; this version posted April 27, 2021. The copyright holder for this preprint (which was not certified by peer review) is the author/funder, who has granted medRxiv a license to display the preprint in perpetuity. It is made available under a CC-BY-NC-ND 4.0 International license.

include countermeasures without economical damage, which will lead to lower $R_{0}$. However, a new SARS-CoV-2 variant, VOC 202012/01 was reported to be 43-90\% higher transmissibility than preexisting variants $[37,38]$ and has been appeared also in Japan. It indicates higher $R_{0}$ setting is better for our results. As shown in Fig 4, as $R_{0}$ increased, number of deaths increased exponentially, so that strategies should be chosen by assuming the worst.

Since we used relative volume of population size and salary for each age group for calculation of economic loss, $E$, comparison with other metrics can be done. The annual GDP growth rates for 2019 and 2020 were $0.3 \%$ and $-4.8 \%$, respectively [16]. If we focus on the quarterly GDP growth in 2020 , these values are $-0.6 \%,-8.3 \%, 5.3 \%$ and $2.8 \%$ from the earliest to the latest. If this volume of decline is totally caused from countermeasures and contributes to reduce transmissibility, sufficient decline can be achieved. However, there are many measures to reduce transmissibility without economical damage so that raising each person's awareness of infection control is important.

While our analysis assumed that the entire population would eventually be vaccinated in one year, this assumption would not be accurate in terms of vaccination rate and final percentage of vaccination. Also, vaccination efficacy for transmissibility and deaths were not accurately evaluated [32] and how long its immunity sustains and how protective for new strains it is remains unknown.

There are several limitations to our study. First, our model assumed lockdown intensity could be precisely controlled by policy makers but in practice the actual extent of the contact reduction may not be obvious until a lockdown is in practice. Second, although the results of this study relied highly on parameters, especially contact rates, the contact rates referred to in the present study were based on data from [25], which did not take into account behavioral changes brought about by the COVID-19 pandemic. Third, our analysis excluded children aged from 0 to 15 years old. Several studies suggested children were less likely to contribute to epidemics $[23,38-40]$, the number of children cases has been increasing due to a new variant of SARS-CoV-2. Finally, our model of economic loss considered only the impact of direct behavioral restraint due to the lockdown, and did 
medRxiv preprint doi: https://doi.org/10.1101/2021.04.18.21255682; this version posted April 27, 2021. The copyright holder for this preprint (which was not certified by peer review) is the author/funder, who has granted medRxiv a license to display the preprint in perpetuity. It is made available under a CC-BY-NC-ND 4.0 International license.

not take into account the value that infectious disease victims were expected to produce in the future, which had been taken into account in several previous studies about economic losses by COVID-19 pandemic $[18,41]$. 
medRxiv preprint doi: https://doi.org/10.1101/2021.04.18.21255682; this version posted April 27, 2021. The copyright holder for this preprint (which was not certified by peer review) is the author/funder, who has granted medRxiv a license to display the preprint in perpetuity. It is made available under a CC-BY-NC-ND 4.0 International license .

\section{References}

1. Zhu N, Zhang D, Wang W, Li X, Yang B, Song J, et al. A Novel Coronavirus from Patients with Pneumonia in China, 2019. N Engl J Med. 2020;382: 727-733.

doi:10.1056/NEJMoa2001017

2. Lu R, Zhao X, Li J, Niu P, Yang B, Wu H, et al. Genomic characterisation and epidemiology of 2019 novel coronavirus: implications for virus origins and receptor binding. The Lancet. 2020;395: 565-574. doi:10.1016/S0140-6736(20)30251-8

3. WHO Coronavirus (COVID-19) Dashboard | WHO Coronavirus Disease (COVID-19) Dashboard. [cited 1 Apr 2021]. Available: https://covid19.who.int/

4. Tian H, Liu Y, Li Y, Wu C-H, Chen B, Kraemer MUG, et al. An investigation of transmission control measures during the first 50 days of the COVID-19 epidemic in China. Science. 2020;368: 638-642. doi:10.1126/science.abb6105

5. Imperial College COVID-19 Response Team, Flaxman S, Mishra S, Gandy A, Unwin HJT, Mellan TA, et al. Estimating the effects of non-pharmaceutical interventions on COVID-19 in Europe. Nature. 2020;584: 257-261. doi:10.1038/s41586-020-2405-7

6. Hyafil A, Moriña D. Analysis of the impact of lockdown on the reproduction number of the SARS-Cov-2 in Spain. Gaceta Sanitaria. 2020; S0213911120300984. doi:10.1016/j.gaceta.2020.05.003

7. Alfano V, Ercolano S. The Efficacy of Lockdown Against COVID-19: A Cross-Country Panel Analysis. Appl Health Econ Health Policy. 2020;18: 509-517. doi:10.1007/s40258-020-005963 
medRxiv preprint doi: https://doi.org/10.1101/2021.04.18.21255682; this version posted April 27, 2021. The copyright holder for this preprint (which was not certified by peer review) is the author/funder, who has granted medRxiv a license to display the preprint in perpetuity. It is made available under a CC-BY-NC-ND 4.0 International license .

8. Caristia S, Ferranti M, Skrami E, Raffetti E, Pierannunzio D, Palladino R, et al. Effect of national and local lockdowns on the control of COVID-19 pandemic: a rapid review. E\&P. 2020;44: 60-68. doi:10.19191/EP20.5-6.S2.104

9. Ambikapathy B, Krishnamurthy K. Mathematical Modelling to Assess the Impact of Lockdown on COVID-19 Transmission in India: Model Development and Validation. JMIR Public Health Surveill. 2020;6: e19368. doi:10.2196/19368

10. You S, Wang H, Zhang M, Song H, Xu X, Lai Y. Assessment of monthly economic losses in Wuhan under the lockdown against COVID-19. Humanit Soc Sci Commun. 2020;7: 52. doi:10.1057/s41599-020-00545-4

11. Nurchis MC, Pascucci D, Sapienza M, Villani L, D’Ambrosio F, Castrini F, et al. Impact of the Burden of COVID-19 in Italy: Results of Disability-Adjusted Life Years (DALYs) and Productivity Loss. IJERPH. 2020;17: 4233. doi:10.3390/ijerph17124233

12. Mottaleb KA, Mainuddin M, Sonobe T. COVID-19 induced economic loss and ensuring food security for vulnerable groups: Policy implications from Bangladesh. Zereyesus Y, editor. PLoS ONE. 2020;15: e0240709. doi:10.1371/journal.pone.0240709

13. Hale T, Angrist N, Goldszmidt R, Kira B, Petherick A, Phillips T, et al. A global panel database of pandemic policies (Oxford COVID-19 Government Response Tracker). Nat Hum Behav. 2021 [cited 29 Mar 2021]. doi:10.1038/s41562-021-01079-8

14. Tan-Torres Edejer T, Hanssen O, Mirelman A, Verboom P, Lolong G, Watson OJ, et al. Projected health-care resource needs for an effective response to COVID-19 in 73 low-income and middle-income countries: a modelling study. The Lancet Global Health. 2020;8: e1372e1379. doi:10.1016/S2214-109X(20)30383-1 
medRxiv preprint doi: https://doi.org/10.1101/2021.04.18.21255682; this version posted April 27, 2021. The copyright holder for this preprint (which was not certified by peer review) is the author/funder, who has granted medRxiv a license to display the preprint in perpetuity. It is made available under a CC-BY-NC-ND 4.0 International license .

15. The Global Economic Outlook During the COVID-19 Pandemic: A Changed World. In: World Bank [Internet]. [cited 1 Apr 2021]. Available:

https://www.worldbank.org/en/news/feature/2020/06/08/the-global-economic-outlook-duringthe-covid-19-pandemic-a-changed-world

16. Cabinet Office. System of National Accounts. [cited 1 Apr 2021]. Available: https://www.esri.cao.go.jp/jp/sna/menu.html

17. Coronavirus (COVID-19) Vaccinations - Statistics and Research. In: Our World in Data [Internet]. [cited 1 Apr 2021]. Available: https://ourworldindata.org/covid-vaccinations

18. Acemoglu D, Chernozhukov V, Werning I, Whinston M. Optimal Targeted Lockdowns in a Multi-Group SIR Model. Cambridge, MA: National Bureau of Economic Research; 2020 May p. w27102. Report No.: w27102. doi:10.3386/w27102

19. SciPy 1.0 Contributors, Virtanen P, Gommers R, Oliphant TE, Haberland M, Reddy T, et al. SciPy 1.0: fundamental algorithms for scientific computing in Python. Nat Methods. 2020;17: 261-272. doi:10.1038/s41592-019-0686-2

20. Storn R, Price K. Differential Evolution - A Simple and Efficient Heuristic for global Optimization over Continuous Spaces. Journal of Global Optimization. 1997;11: 341-359. doi:10.1023/A:1008202821328

21. Tillett RL, Sevinsky JR, Hartley PD, Kerwin H, Crawford N, Gorzalski A, et al. Genomic evidence for reinfection with SARS-CoV-2: a case study. The Lancet Infectious Diseases. 2021;21: 52-58. doi:10.1016/S1473-3099(20)30764-7 
medRxiv preprint doi: https://doi.org/10.1101/2021.04.18.21255682; this version posted April 27, 2021. The copyright holder for this preprint (which was not certified by peer review) is the author/funder, who has granted medRxiv a license to display the preprint in perpetuity. It is made available under a CC-BY-NC-ND 4.0 International license .

22. Diekmann O, Heesterbeek JAP, Roberts MG. The construction of next-generation matrices for compartmental epidemic models. J R Soc Interface. 2010;7: 873-885.

doi:10.1098/rsif.2009.0386

23. CMMID COVID-19 working group, Davies NG, Klepac P, Liu Y, Prem K, Jit M, et al. Agedependent effects in the transmission and control of COVID-19 epidemics. Nat Med. 2020;26: 1205-1211. doi:10.1038/s41591-020-0962-9

24. Ferretti L, Wymant C, Kendall M, Zhao L, Nurtay A, Abeler-Dörner L, et al. Quantifying SARS-CoV-2 transmission suggests epidemic control with digital contact tracing. Science. 2020;368: eabb6936. doi:10.1126/science.abb6936

25. Prem K, Cook AR, Jit M. Projecting social contact matrices in 152 countries using contact surveys and demographic data. Halloran B, editor. PLoS Comput Biol. 2017;13: e1005697. doi:10.1371/journal.pcbi.1005697

26. Levin AT, Hanage WP, Owusu-Boaitey N, Cochran KB, Walsh SP, Meyerowitz-Katz G. Assessing the age specificity of infection fatality rates for COVID-19: systematic review, metaanalysis, and public policy implications. Eur J Epidemiol. 2020;35: 1123-1138. doi:10.1007/s10654-020-00698-1

27. Ministry of Internal Affairs and Communications. Population Estimates, Monthly Report in September 1, 2020 (Final estimates), February 1, 2021 (Provisional estimates). [cited 3 Mar 2021]. Available: https://www.e-stat.go.jp/statsearch/files?page $=1 \&$ layout $=$ datalist $\&$ toukei $=00200524 \&$ tstat $=000000090001 \&$ cycle $=1 \&$ year $=20210 \&$ month $=11010302 \&$ tclass $1=000001011678 \&$ tclass $2 \mathrm{val}=0$ 
medRxiv preprint doi: https://doi.org/10.1101/2021.04.18.21255682; this version posted April 27, 2021. The copyright holder for this preprint (which was not certified by peer review) is the author/funder, who has granted medRxiv a license to display the preprint in perpetuity. It is made available under a CC-BY-NC-ND 4.0 International license .

28. Ministry of Health, Labour and Welfare. Open data in "About Coronavirus Disease 2019(COVID-19).” [cited 3 Mar 2021]. Available: https://www.mhlw.go.jp/stf/covid-19/opendata.html

29. Ministry of Health, Labour and Welfare. Basic Survey on Wage Structure. [cited 3 Mar 2021]. Available: https://www.e-stat.go.jp/statsearch/files?page $=1 \&$ toukei $=00450091 \&$ tstat $=000001011429$

30. Ministry of Health, Labour and Welfare. Survey on Employment Trends. [cited 3 Mar 2021]. Available: https://www.e-stat.go.jp/statsearch/files?page $=1 \&$ toukei $=00450073 \&$ tstat $=000001012468$

31. Polack FP, Thomas SJ, Kitchin N, Absalon J, Gurtman A, Lockhart S, et al. Safety and Efficacy of the BNT162b2 mRNA Covid-19 Vaccine. N Engl J Med. 2020;383: 2603-2615. doi:10.1056/NEJMoa2034577

32. Dagan N, Barda N, Kepten E, Miron O, Perchik S, Katz MA, et al. BNT162b2 mRNA Covid19 Vaccine in a Nationwide Mass Vaccination Setting. N Engl J Med. 2021; NEJMoa2101765. doi:10.1056/NEJMoa2101765

33. Alimohamadi Y, Taghdir M, Sepandi M. Estimate of the Basic Reproduction Number for COVID-19: A Systematic Review and Meta-analysis. J Prev Med Public Health. 2020;53: 151157. doi:10.3961/jpmph.20.076

34. Park M, Cook AR, Lim JT, Sun Y, Dickens BL. A Systematic Review of COVID-19 Epidemiology Based on Current Evidence. JCM. 2020;9: 967. doi:10.3390/jcm9040967

35. Kretzschmar ME, Rozhnova G, Bootsma MCJ, van Boven M, van de Wijgert JHHM, Bonten MJM. Impact of delays on effectiveness of contact tracing strategies for COVID-19: a 
medRxiv preprint doi: https://doi.org/10.1101/2021.04.18.21255682; this version posted April 27, 2021. The copyright holder for this preprint (which was not certified by peer review) is the author/funder, who has granted medRxiv a license to display the preprint in perpetuity. It is made available under a CC-BY-NC-ND 4.0 International license.

modelling study. The Lancet Public Health. 2020;5: e452-e459. doi:10.1016/S24682667(20)30157-2

36. Bao C, Pan E, Ai J, Dai Q, Xu K, Shi N, et al. COVID-19 outbreak following a single patient exposure at an entertainment site: An epidemiological study. Transbound Emerg Dis. 2020; tbed.13742. doi:10.1111/tbed.13742

37. Leung K, Shum MH, Leung GM, Lam TT, Wu JT. Early transmissibility assessment of the N501Y mutant strains of SARS-CoV-2 in the United Kingdom, October to November 2020. Eurosurveillance. 2021;26. doi:10.2807/1560-7917.ES.2020.26.1.2002106

38. Davies NG, Abbott S, Barnard RC, Jarvis CI, Kucharski AJ, Munday JD, et al. Estimated transmissibility and impact of SARS-CoV-2 lineage B.1.1.7 in England. Science. 2021; eabg3055. doi:10.1126/science.abg3055

39. Monod M, Blenkinsop A, Xi X, Hebert D, Bershan S, Tietze S, et al. Age groups that sustain resurging COVID-19 epidemics in the United States. Science. 2021; eabe8372. doi:10.1126/science.abe8372

40. Doyle T, Kendrick K, Troelstrup T, Gumke M, Edwards J, Chapman S, et al. COVID-19 in Primary and Secondary School Settings During the First Semester of School Reopening — Florida, August-December 2020. MMWR Morb Mortal Wkly Rep. 2021;70. doi:10.15585/mmwr.mm7012e2

41. Alvarez FE, Argente D, Lippi F. A Simple Planning Problem for COVID-19 Lockdown. National Bureau of Economic Research; 2020 Apr. Report No.: w26981. doi:10.3386/w26981 
medRxiv preprint doi: https://doi.org/10.1101/2021.04.18.21255682; this version posted April 27, 2021. The copyright holder for this preprint

(which was not certified by peer review) is the author/funder, who has granted medRxiv a license to display the preprint in perpetuity.

\section{Supporting information}

S1 Table. Numerical results for the beset strategy among all to minimize the cumulative number of deaths imposing same intensity of the lockdown to all age groups.

S2 Table. Numerical results for the beset strategy among all to minimize the cumulative number of deaths imposing same intensity of the lockdown to all age groups.

S3 Fig. The optimized results for $\mathrm{R} 0=1.3$ when the lockdown was imposed with different intensities to each age group. The optimized results of the cumulative number of deaths and infected population for each economic loss is presented. Three lines of young first vaccination strategies have overlain each other. The order of age groups on the label shows vaccine allocation strategies.

S4 Fig. The optimized parameters for $\mathrm{R} 0=1.3$ when the lockdown was imposed with different intensities to each age group. Each figure block contains lockdown intensities for young (blue), middle (yellow) and old (blue) age group and lockdown length (red). 